\title{
Kinetics and Mechanistic Studies of Oxidation of a Ternary Nitrilotri-Acetatocobalt(II) Complexes Involving DL-valine and DL-aspartic Acid as a Secondary Ligands by Periodate
}

\author{
Ahmed A. Abdel-Khalek, Hassan A. Ewais, Eman S. H. Khaled, Abeer A. Atia \\ Chemistry Department, Faculty of Science, Beni-Suef University, Beni-Suef City, Eygpt \\ Email address: \\ abeeraatia@yahoo.com (A. A. Atia) \\ To cite this article: \\ Ahmed A. Abdel-Khalek, Hassan A. Ewais, Eman S. H. Khaled, Abeer A. Atiaa. Kinetics and Mechanistic Studies of Oxidation of a Ternary \\ Nitrilotri-Acetatocobalt(II) Complexes Involving DL-valine and DL-aspartic Acid as a Secondary Ligands by Periodate. World Journal of \\ Applied Chemistry. Vol. 2, No. 1, 2017, pp. 24-33. doi: 10.11648/j.wjac.20170201.14
}

Received: October 25, 2016; Accepted: December 9, 2016; Published: March 2, 2017

\begin{abstract}
Oxidation of ternary complexes, $\left[\mathrm{Co}^{\mathrm{II}}(\mathrm{NTA})(\mathrm{L})\left(\mathrm{H}_{2} \mathrm{O}\right)_{\mathrm{X}}\right]^{\mathrm{n}}$ by periodate in aqueous medium has been studied spectrophotometrically over the $(25.0-45.0) \pm 0.1^{\circ} \mathrm{C}$ range. The reaction show first order kinetics with respect to both $\left[\mathrm{IO}_{4}{ }^{-}\right]$ and the complexes, and the rate of the reaction increases over the $\left[\mathrm{H}^{+}\right]$range $(1.05-28.20) \times 10^{-5} \mathrm{~mol} \mathrm{dm}^{-3}$ in both cases. Preparation and characterization of $\left[\mathrm{Co}^{\mathrm{II}}(\mathrm{NTA})(\mathrm{Asp})\left(\mathrm{H}_{2} \mathrm{O}\right)_{2}\right]^{-3}$ and $\left[\mathrm{Co}^{\mathrm{II}}(\mathrm{NTA}) \mathrm{Val}\left(\mathrm{H}_{2} \mathrm{O}\right)_{2}\right]^{2-}$ is performed. Conformation of the formation of the ternary complexes has been done using IR spectrum, TGA, UV-visible spectroscopic and cyclic voltammetry measurements. The thermodynamic activation parameters have been calculated. It is assumed that electron transfer takes place via an inner-sphere mechanism.
\end{abstract}

Keywords: Kinetics, Ternary Co(II) Complexes, Aspartic acid, DL-Valin, UV-spectrophotometer, Inner-Sphere Mechanism, Thermodynamic Activation Parameters

\section{Introduction}

Amino acid residues are the main constituents of proteins and the study of its sensitivity towards oxidation open up a new area to understand the mechanism involved in the protein and amino acid modification [1].

The use of transition metal complexes of nitrilotriacetic acid have been widely adopted in biology, and are gaining increasing use in biotechnology, particularly in the protein purification technique known as immobilized metal-ion [2].

Ternary complexes of oxygen-donor ligands and heteroaromatic $N$-bases have attracted much interest as they can display exceptionally high stability and biological important $[3,4]$.

Periodate oxidation exerts a number of biological effects including the enhancement of lymphocyte activation and increased the frequency of effecter to target cell binding [5]. Also, periodate was used in the modification of human serum transferrin by conjugation to oligosaccharide [6].

Oxidation of caffeic acid (3,4-dihydroxycinnamic acid) by means of sodium periodate was reported, that mimics the mechanism of polyphenyleoxidase. The reaction leads to the formation of the antioxidant product 2-S-cysteinylecaffeic adduct which exhibits slightly improved antiradical activity in relation with the parent molecule (caffeic acid) [7]. Also, kinetics studies of periodate oxidations on a series of dextran oligomers, polymers, some dimeric carbohydrates [8] and of chitosans with different chemical composition [9] were investigated to show the dependence of the kinetics on the molecular weight.

Using periodate as an oxidant for inorganic substrates and some transition metals are reported to proceed via an innersphere mechanism [10-15]. Periodate readily found to oxidize either labile or inert complexes possessing at least one bridging ligand. Initial cobalt(III) products that were transformed to the final cobalt(III) products slowly were identified spectrophotometrically [13-15].

Oxidation of the ternary complexes involving nitrilotriacetatocobaltate(II) succinic acid, $\left[\mathrm{Co}^{\mathrm{II}} \mathrm{NS}\left(\mathrm{H}_{2} \mathrm{O}\right)_{2}\right]^{3-}$, and nitrilotriacetatocobaltate(II) malonic acid], $\left[\mathrm{Co}{ }^{\mathrm{II}} \mathrm{NM}\left(\mathrm{H}_{2} \mathrm{O}\right)_{2}\right]^{3-}$ [where $\mathrm{N}=$ nitrilotriacetate, $\mathrm{S}=$ succinic acid, and $\mathrm{M}=$ malonic acid] by periodate has been studied in aqueous medium [16].

Also, oxidation of $\left[\mathrm{Co}^{\mathrm{II}} \mathrm{NMa}\left(\mathrm{H}_{2} \mathrm{O}\right)\right]^{3-} .4 \mathrm{H}_{2} \mathrm{O}$ and 
$\left[\mathrm{Co}^{\mathrm{II}} \mathrm{NT}\left(\mathrm{H}_{2} \mathrm{O}\right)\right]^{3-} .4 \mathrm{H}_{2} \mathrm{O}$ by periodate have been studied kinetically in aqueous solution [where, $\mathrm{N}=$ nitrilotriacetate, $\mathrm{Ma}=$ Maleic acid, and $\mathrm{T}=$ tartaric acid] over $25-45^{\circ} \mathrm{C}$ and a variety ofpH range [17].

The oxidation of $\left[\mathrm{Co}^{\mathrm{II}}(\mathrm{nta})(\mathrm{ox})\left(\mathrm{H}_{2} \mathrm{O}\right)_{2}\right]^{3-}$ and $\left[\mathrm{Co}^{\mathrm{II}}(\mathrm{nta})(\mathrm{ph})\left(\mathrm{H}_{2} \mathrm{O}\right)_{2}\right]^{3-}(\mathrm{nta}=$ nitrilotriacetate, ox $=$ oxalic acid and $\mathrm{ph}=$ phthalic acid) by periodate have been studied kinetically in aqueous solution over $20-40^{\circ} \mathrm{C}$ and a variety of $\mathrm{pH}$ ranges [18], These reactions proceeded via the formation of initial cobalt (III) products, which were converted slowly into final cobalt (III) products fitting an inner-sphere mechanism.

A kinetic study of the oxidation of $\left[\mathrm{Co}\left(\mathrm{H}_{2} \mathrm{~L}\right)\left(\mathrm{H}_{2} \mathrm{O}\right)_{2}\right]^{2+}$ $\left(\mathrm{H}_{2} \mathrm{~L}=\mathrm{N}, \mathrm{N}\right.$-bis (salicylaldehyde-1,2-diaminoethane) Schiff base) by periodate in aqueous solution was performed reaction was inhibited as the concentration of $\mathrm{Cu}$ (II) increased, and it was independent on Fe(II) concentrations over the ranges studied. An inner-sphere mechanism is proposed for the oxidation pathways of both the protonated and deprotonated $\mathrm{Co}^{\mathrm{II}}$ complex species [19].

The aim of the present study is to propose the most probable reaction path for the kinetics of oxidation of biologically important ternary nitrilotri-acetatocobalt(II) complexes involving DL-valine and DL-aspartic acid as a secondary ligands. $\left[\mathrm{Co}^{\mathrm{II}}(\mathrm{NTA})(\mathrm{L})\left(\mathrm{H}_{2} \mathrm{O}\right)_{\mathrm{X}}\right]^{-\mathrm{n}}$ where $(\mathrm{NTA}=$ nitrilotriactate acid, $\mathrm{L}=$ aspartic acid, Val $=$ DL-valin, $\mathrm{x}=$ no of coordinated water molecule, and $\mathrm{n}=$ no of negative charge).

Choice of these ternary complexes was attributed to two considerations. Firstly, study the effect of aspartate and DLvalin as a secondary ligand on the stability of $\left[\mathrm{Co}{ }^{\mathrm{II}} \mathrm{NTA}\left(\mathrm{H}_{2} \mathrm{O}\right)_{2}\right]^{-}$towards oxidation and the reaction pathways. Secondly, study the effect of secondary ligand on the biological activity of NTA and $\left[\mathrm{Co}^{\mathrm{II}}\left(\mathrm{NTA}\left(\mathrm{H}_{2} \mathrm{O}\right)_{2}\right]^{-}\right.$.

\section{Experimental}

\subsection{Materials and Methods}

All reagent grade or analar chemicals were used without further purification. $\mathrm{Co}\left(\mathrm{NO}_{3}\right)_{2} \quad(\mathrm{BDH})$ solutions were standardized volumetrically with EDTA [20]. A stock solution of $\left(\mathrm{IO}_{4}\right)^{-}$was made up by weight and covered with aluminum foil to avoid photochemical decomposition [21]. Solutions of $\mathrm{NaOAC}, \mathrm{HOAC}$, and $\mathrm{NaNO}_{3}$ were prepared by weighing.

HOAC / NaOAC buffers of known $\left[\mathrm{H}^{+}\right]$were used, and the ionic strength was adjusted with $\mathrm{NaNO}_{3}$.

Potentiometric measurements were performed with a Metrohm 702 SM titrino. The titroprocessor equipped with a 665 dosimat (Switzerland-Heriau). The titroprocessor and electrode were calibrated with standard buffer solution [22].

Calculations were performed using computer program MINIQUAD-75 loaded on an IBM-550 computer. The solution containing $5.0 \mathrm{ml} 0.01 \mathrm{~mol} \mathrm{dm}^{-3}$ complex, $5.0 \mathrm{ml}$ $0.20 \mathrm{~mol} \mathrm{dm}^{-3} \mathrm{NaNO}_{3}, 5 \mathrm{ml} 0.04 \mathrm{~mol} \mathrm{dm}^{-3} \mathrm{HNO}_{3}$ and $25 \mathrm{ml}$ deionized water, was titrated with $0.01 \mathrm{~mol} \mathrm{dm}^{-3} \mathrm{NaOH}$ at $25^{\circ} \mathrm{C}$.

$\mathrm{Na}_{3}\left[\mathrm{Co}^{\mathrm{II}}(\mathrm{NTA}) \operatorname{Asp}\left(\mathrm{H}_{2} \mathrm{O}\right)_{2}\right]$ and $\mathrm{Na}_{2}\left[\mathrm{Co}^{\mathrm{II}}(\mathrm{NTA}) \operatorname{Val}\left(\mathrm{H}_{2} \mathrm{O}\right)_{2}\right]$ were prepared using the same procedure as that for the preparation of $\mathrm{Na}_{3}\left[\mathrm{Co}{ }^{\mathrm{II}} \mathrm{NS}\left(\mathrm{H}_{2} \mathrm{O}\right)_{2}\right]$ [23]. The elemental analysis data of these complexes are found: $\mathrm{C}, 25.70 ; \mathrm{H}$, 3.02; N, 6.61. Calcd.: C, 24.84; H, 3.11; N, 5.79 and Found: C, 29.46; H, 5.31; N, 6.21; Calcd.:C, 29.66; H, 4.49; N, 6.29, respectively.

IR spectra, thermal gravimetric analysis (TGA), UV Visible spectra and cyclic voltammetric data were carried out to confirm the formula of the complexes.

IR spectra show bands in the $(3516-3363) \mathrm{cm}^{-1}$ region, were attributed to $v(\mathrm{OH})$ of the water molecules. The $\mathrm{OH}$ of the carboxylic group disappeared and a new $\left(v \mathrm{COO}^{-}\right)$ appeared in the region $(1464-1432) \mathrm{cm}^{-1}$ indicating that the carboxylic group of the ligands participates in the coordination with the metal ions through deprotonation.

All the spectra of the complexes studied showed asym- $(v$ COO-Co) band in the region $(1582-1658) \mathrm{cm}^{-1}$, the bands in the range $(2928-2967) \mathrm{cm}^{-1}$ in the spectra, are due to $v(\mathrm{NH})$ as shown in Figures 1 and 2.

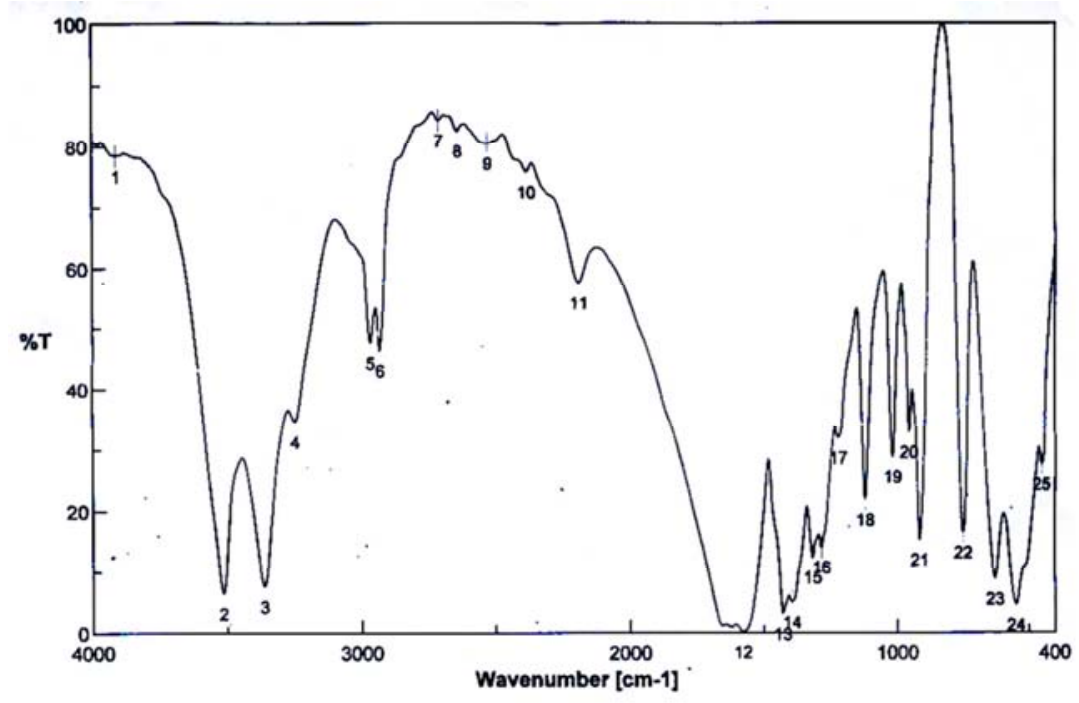

Figure 1. Infrared spectra of nitrilotriacetatocobalt (II)-Valin[Co $\left.{ }^{I I}(\mathrm{NTA})(\mathrm{Val})(\mathrm{H} 2 \mathrm{O}) 2^{-2}\right]$. 


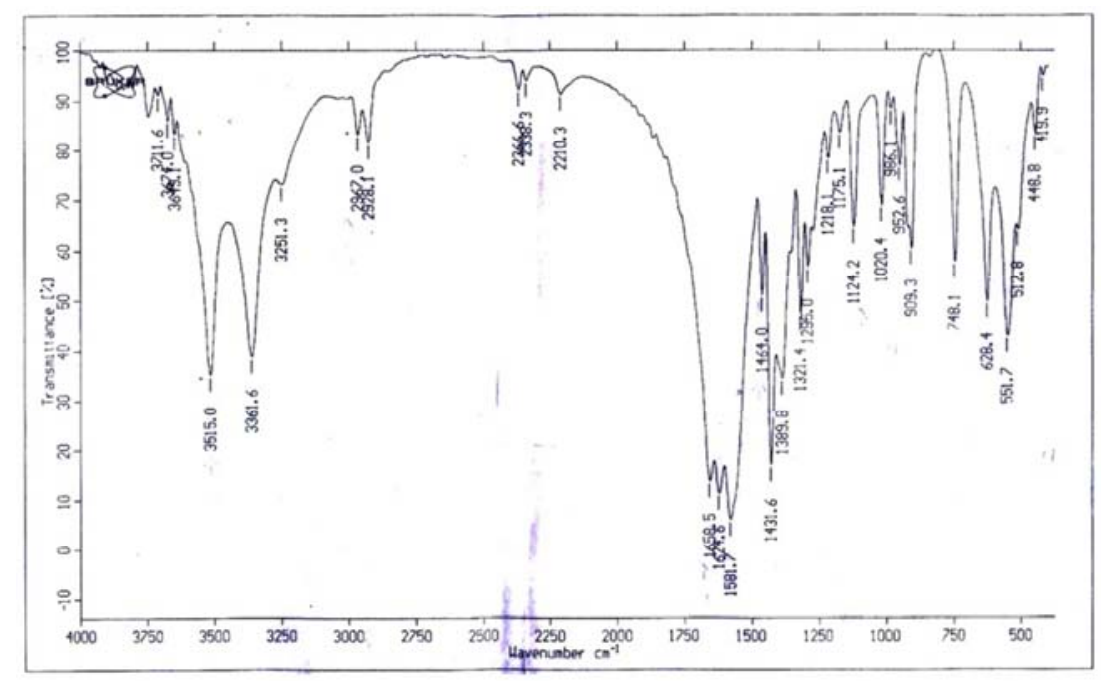

Figure 2. Infrared spectra of nitrilotriacetatocobalt (II)-Aspartate[Co $\left.{ }^{I I}(\mathrm{NTA})(\mathrm{Asp})(\mathrm{H} 2 \mathrm{O}) 2^{-2}\right]$.

The thermogram of the complex $\mathrm{Na}_{3}\left[\mathrm{Co}^{\mathrm{II}}(\mathrm{NTA}) \operatorname{Asp}\left(\mathrm{H}_{2} \mathrm{O}\right)_{2}\right]$ shows weight loss (6.86) at $151.46^{\circ} \mathrm{C}$ corresponds to the loss of two coordinated water molecule (calc. 7.45), and the weight loss (46.32) at $394.2^{\circ} \mathrm{C}$ corresponding to the loss five $\mathrm{CO}_{2}$ molecules (cal. 45.54).
While the thermogram of the $\mathrm{Na}_{2}\left[\mathrm{Co}^{\mathrm{II}}(\mathrm{NTA}) \mathrm{Val}\left(\mathrm{H}_{2} \mathrm{O}\right)_{2}\right]$ complex shows weight loss $(8.84)$ at $145.49^{\circ} \mathrm{C}$ corresponds to the loss of two coordinated water molecules (calc. 8.09), and weight loss $(40.62)$ at $400.64^{\circ} \mathrm{C}$ corresponding to the loss four $\mathrm{CO}_{2}$ molecules (cal. 39.55) as shown in Figures 3 and 4.

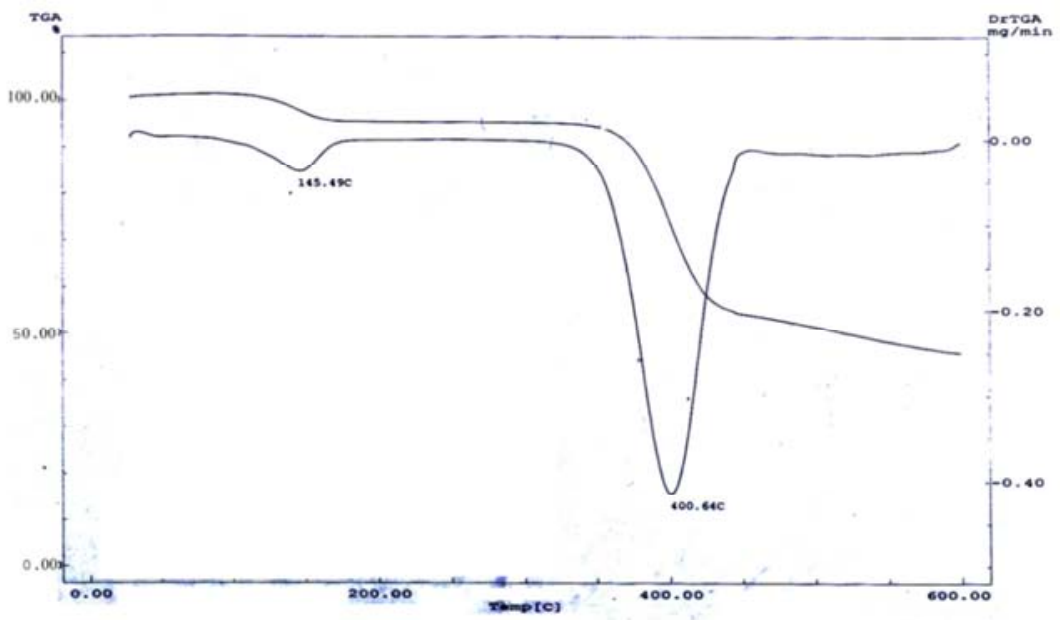

Figure 3. Thermal decomposition curve of nitrilotriacetatocobalt(II) $-\operatorname{Valin}\left[\mathrm{Co}^{I I}(\mathrm{NTA})(\mathrm{Val})(\mathrm{H} 2 \mathrm{O}) 2^{-2}\right]$.

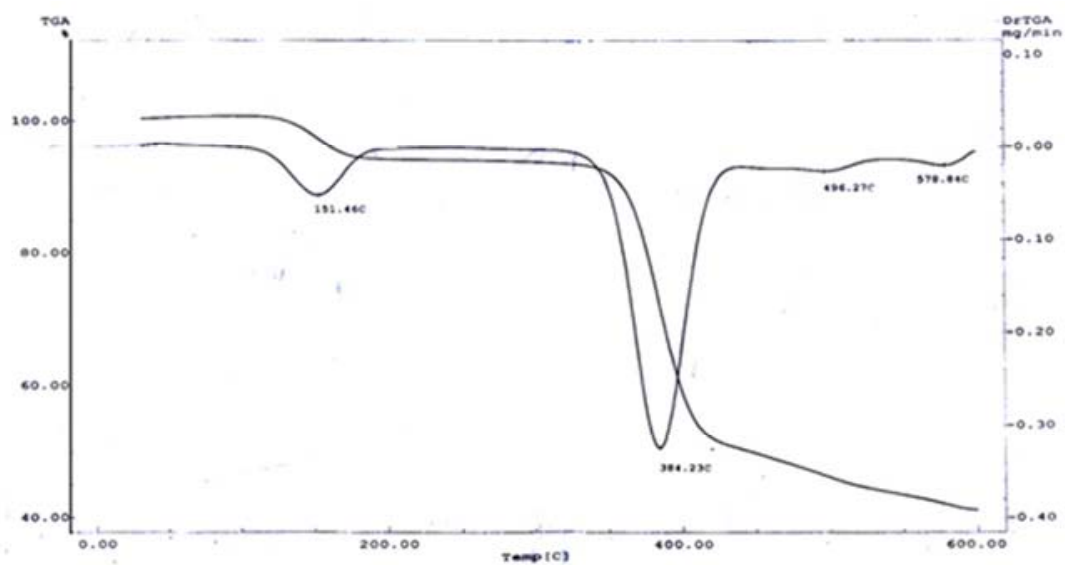

Figure 4. Thermal decomposition curve of nitrilotriacetatocobalt(II)-Aspartate $\left[\mathrm{Co}^{I I}(\mathrm{NTA})(\mathrm{Asp})(\mathrm{H} 2 \mathrm{O}) 2^{-2}\right]$. 
Confirmation of the formation of binary and ternary complexes in solution has been carried out by studying the electrochemical behavior (Figures 5-8). Cyclic Voltametric measurements were operated using potentiostat / Galvaostate winking PGS 95 with single-compartment Voltametric cell equipped with a platinum working electrode (area $=0.5 \mathrm{~cm}^{2}$ ). A platinum wire was used as counter electrode, and a SCE as reference electrode. A sample volume of $25 \mathrm{~cm}^{2}$ containing the free metal ion $3 \times 10^{-3} \mathrm{~mol} \mathrm{dm}^{-3}$, ternary complex $3 \times 10^{-3}$ $\mathrm{mol} \mathrm{dm}{ }^{-3}$. All solutions are investigated in water at $30^{\circ} \mathrm{C}$, the solutions are purged with nitrogen for $120 \mathrm{~s}$, and the potential is scanned at the scan rate $25 \mathrm{MVs}^{-1}$ from $(+1.5$ to -1.0$) \mathrm{V}$.

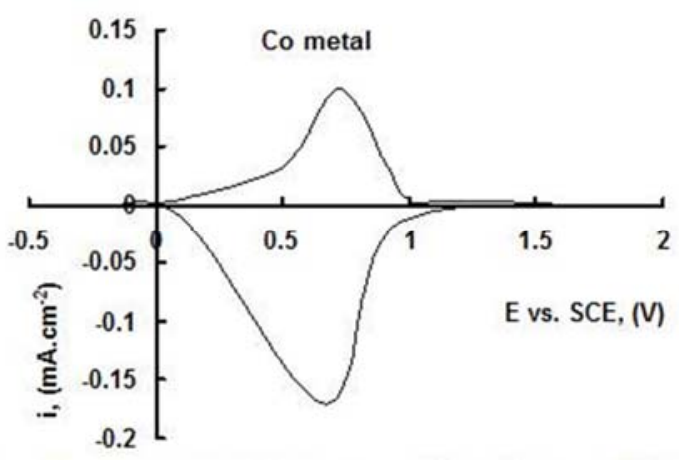

Figure 5. Cyclic voltammogram for the $3 \times 10^{-3} \mathrm{M}$ of CO(II) solution on $\mathrm{Pt}$ electrode at $300 \mathrm{~K}$ with the scan rate of $25 \mathrm{mVs}^{-1}$.

\section{Co-NTA complex}

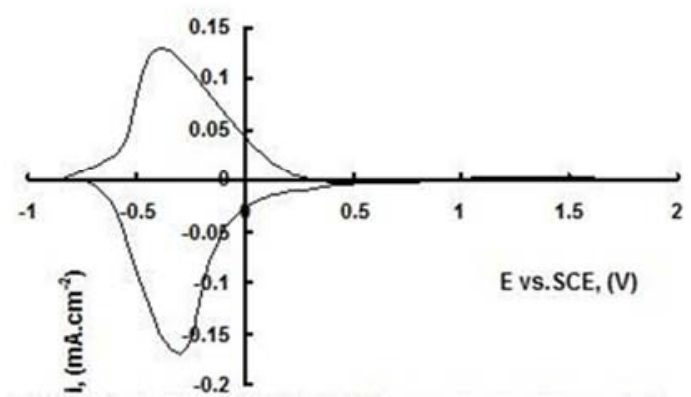

Figure 6. Cyclic voltammogram for the $3 \times 10^{-3} \mathrm{M}$ of CO(II)-NTA solution on Pt electrode at $300 \mathrm{~K}$ with the scan rate of $25 \mathrm{mVs}^{-1}$.

Co-NTA-Val complex

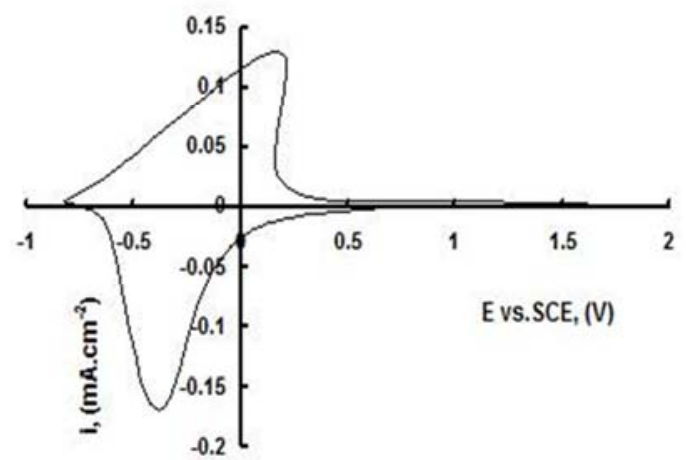

Figure 7. Cyclic voltammogram for the $3 \times 10^{-3} \mathrm{M}$ of CO(II)-NTA-Val solution on Pt electrode at $300 \mathrm{~K}$ with the scan rate of $25 \mathrm{mVs}^{-1}$.

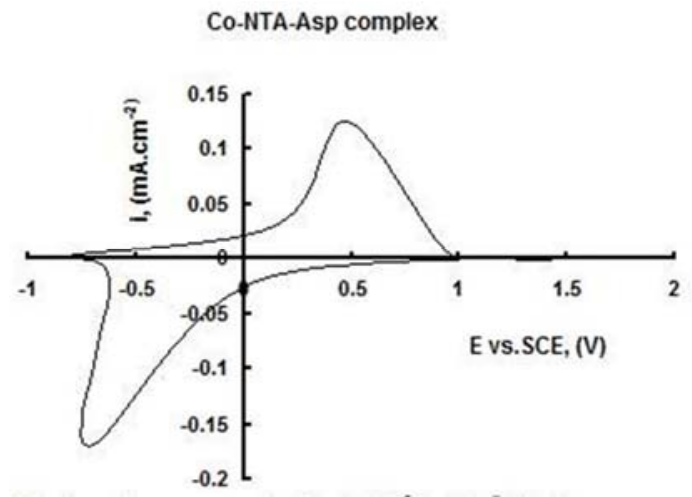

Figure 8. Cyclic voltammogram for the $3 \times 10^{-3} \mathrm{M}$ of CO(II)-NTA-Asp solution on Pt electrode at $300 \mathrm{~K}$ with the scan rate of $25 \mathrm{mVs}^{-1}$.

Metal cobalt ion is difficulty oxidized at more positive potential, $+732 \mathrm{mV} v s$. SCE, Figure (3), but the oxidation process of the binary system of $\mathrm{Co}(\mathrm{II})$-nitrilotriacetate becomes slightly easy where the oxidation potential was shifted to more negative value, $-375 \mathrm{mV} v s$. SCE, while in the case of ternary complex involving (aspartic with nitrilotriacetato-cobalt(II), the complex become more stable than binary complex, $+478 \mathrm{mV} v s$. SCE), but in case of ternary complex involving (valin with nitrilotriacetatocobalt(II), the complex become less stable than $\left.\mathrm{Co}^{\mathrm{II}}(\mathrm{NTA}) \mathrm{Asp}\left(\mathrm{H}_{2} \mathrm{O}\right)_{2}\right]^{3-}$, because it oxidizes firstly, at +179 $\mathrm{mV} v$ s. SCE.

\subsection{Kinetic Procedures}

The U.V.-visible absorption spectra (Figures 9 and 10) of each species of solution containing $\mathrm{Co}^{\mathrm{II}}$, $\left[\mathrm{Co}^{\mathrm{II}}(\mathrm{NTA})\left(\mathrm{H}_{2} \mathrm{O}\right)_{2}\right]^{\text {, }}$, $\left[\mathrm{Co}^{\mathrm{II}}(\mathrm{NTA})(\mathrm{Asp})\left(\mathrm{H}_{2} \mathrm{O}\right)_{2}\right]^{-3}, \quad\left[\mathrm{Co}^{\mathrm{II}}(\mathrm{NTA})(\mathrm{Val})\left(\mathrm{H}_{2} \mathrm{O}\right)_{2}\right]^{-2}$ at the concentration $\left(4.0 \times 10^{-3} \mathrm{~mol} \mathrm{dm}^{-3}\right)$ and $\left[\mathrm{H}^{+}\right]=4.36 \times 10-^{5} \mathrm{~mol}$ $\mathrm{dm}^{-3}$ exhibited an absorption bands over the range of 300-700 $\mathrm{nm}$ figure $(1,2)$. The maxima and molar absorptivity of these compounds were collected Table (1). Peaks shifting and molar absorptivity indicated the formation of complex $\left[\mathrm{Co}^{\mathrm{II}}(\mathrm{NTA})(\mathrm{Asp})\left(\mathrm{H}_{2} \mathrm{O}\right)_{2}\right]^{-3},\left[\mathrm{Co}^{\mathrm{II}}(\mathrm{NTA})(\mathrm{Val})\left(\mathrm{H}_{2} \mathrm{O}\right)_{2}\right]^{-2}$.

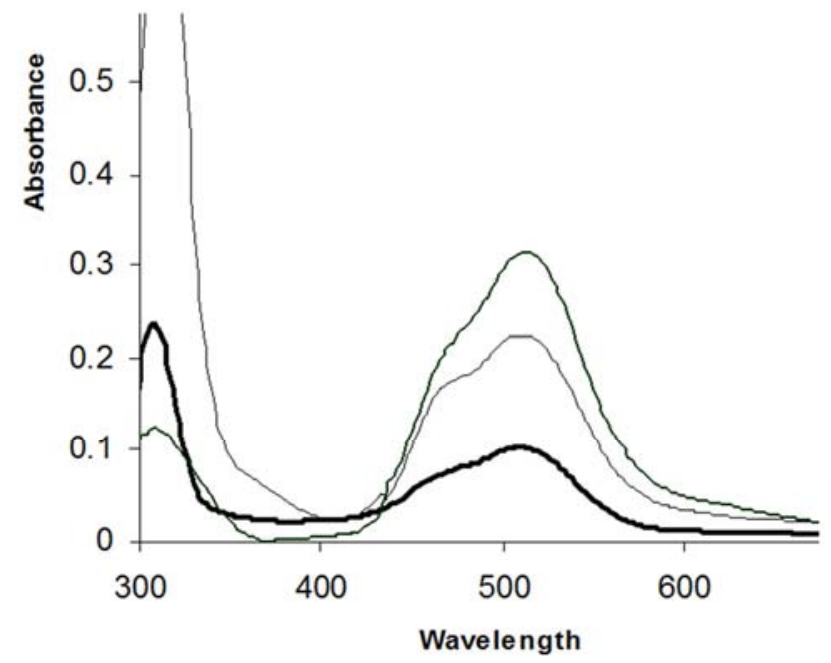

Figure 9. Change in absorbance for $\left(\mathrm{Co}^{I I}\right)\left(\mathrm{Co}^{I I}(\mathrm{NTA})\right.$, and $\mathrm{Co}^{I I}(\mathrm{NTA}) \mathrm{Asp}$ at the same concentration $\left(4 \times 10^{-3} \mathrm{moldm}^{-3}\right)$, and $\mathrm{pH}=5$. 


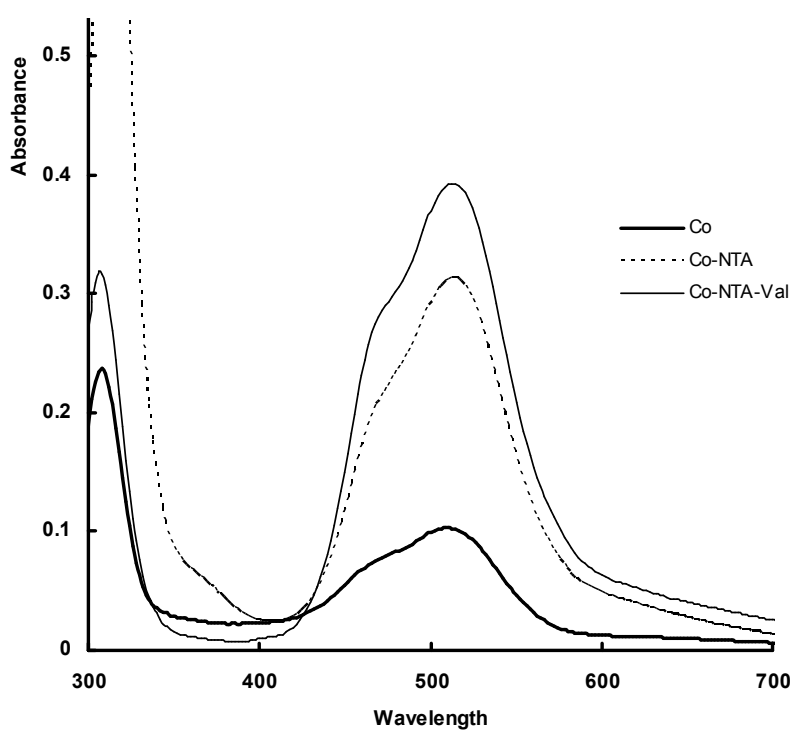

Figure 10. Change in absorbance for $\left(\mathrm{Co}^{I I}\right), \mathrm{Co}^{I I}(N T A)$, and $\mathrm{Co}^{I I}(N T A)$ Val. At the same concentration $\left(4 \times 10^{-3} \mathrm{moldm}^{-3}\right), \mathrm{pH}=5$.

Milton-Roy 601 spectrophotometer equipped with a temperature cell holder and connected to a thermo-circulating water bath, was used to measure the oxidation rates by monitoring the absorbance of initial $\mathrm{Co}^{\mathrm{III}}$ complexes absorbance at 572 and $558 \mathrm{~nm}$, respectively. All reactants, except $\mathrm{IO}_{4}^{-}$, were equilibrated at required temperature for 15 $20 \mathrm{~min}$. The required amount of separately thermostated $\mathrm{IO}_{4}^{-}$ stock solution was rapidly mixed, and then the recording of absorbance was commenced.

The $\left[\mathrm{H}^{+}\right]$of the reaction mixture was measured using a Chertsey, Surrey, $7065 \mathrm{pH}$-meter.

Pseudo-first order conditions were maintained in all runs by the presence of a large excess of $\mathrm{IO}_{4}^{-},(>10$-fold). The ionic strength was kept constant by addition of $\mathrm{NaNO}_{3}$ solution. The $\left[\mathrm{H}^{+}\right]$of the reaction mixture was found to be always constant during the reaction run.

The error limits for results are calculated using Microcal TM Origin ${ }^{\circledR}$ (Version 6.0).

\subsection{Oxidation Product}

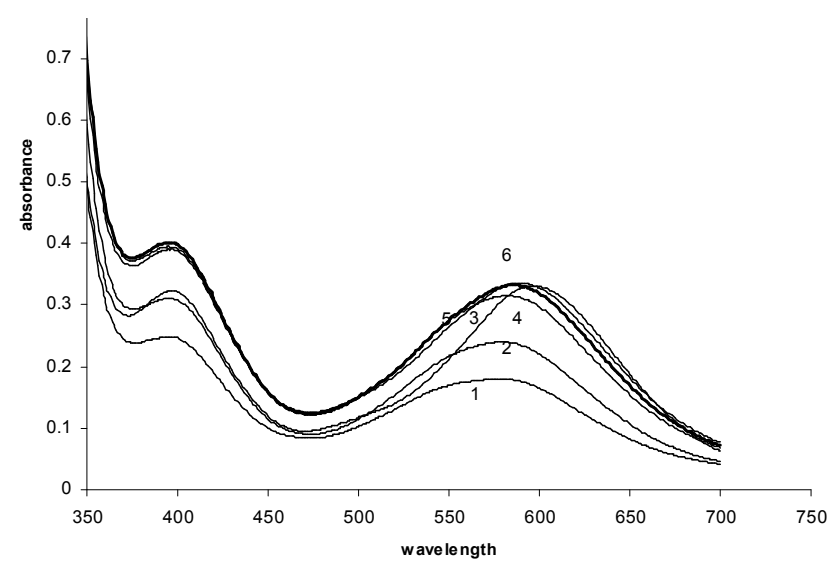

Figure 11. Change in absorbance as a function of time in the reaction between $\left[\mathrm{Co}^{\mathrm{II}}(\mathrm{NTA}) \mathrm{Asp}\left(\mathrm{H}_{2} \mathrm{O}\right)_{2}\right]^{3-}$ and $\left[\mathrm{IO}_{4}\right]^{-}$. Curve (6) shows the spectra of the final cobalt (III) product.
The U.V.-vis. Absorption spectra of the oxidation product of $\left[\mathrm{Co}^{\mathrm{II}}(\mathrm{NTA}) \mathrm{Asp}\left(\mathrm{H}_{2} \mathrm{O}\right)_{2}\right]^{3-}$ and $\left[\mathrm{Co}^{\mathrm{II}}(\mathrm{NTA}) \mathrm{Val}\left(\mathrm{H}_{2} \mathrm{O}\right)_{2}\right]^{2-}$ by periodate were recorded on Jasco UV-530 spectrophotometer as a function of time over the $300-700 \mathrm{~nm}$ range (Figures 11 and 12) respectively. The maxima and molar absorptivity coefficients of the final cobalt (III) product at $\left[\mathrm{H}^{+}\right]=4.36 \mathrm{x}$ $10-^{5} \mathrm{~mol} \mathrm{dm}^{-3}$ of oxidation of aspartic ternary complex were $\varepsilon_{\max }{ }^{395}=158$ and $\varepsilon_{\max }{ }^{572}=135 \mathrm{dm}^{3} \mathrm{~mol}^{-1} \mathrm{~cm}^{-1}$, while the coefficients of the valin ternary complex were $\varepsilon_{\max }{ }^{395}=156$ and $\varepsilon_{\max }^{558}=157 \mathrm{dm}^{3} \mathrm{~mol}^{-1} \mathrm{~cm}^{-1}$.

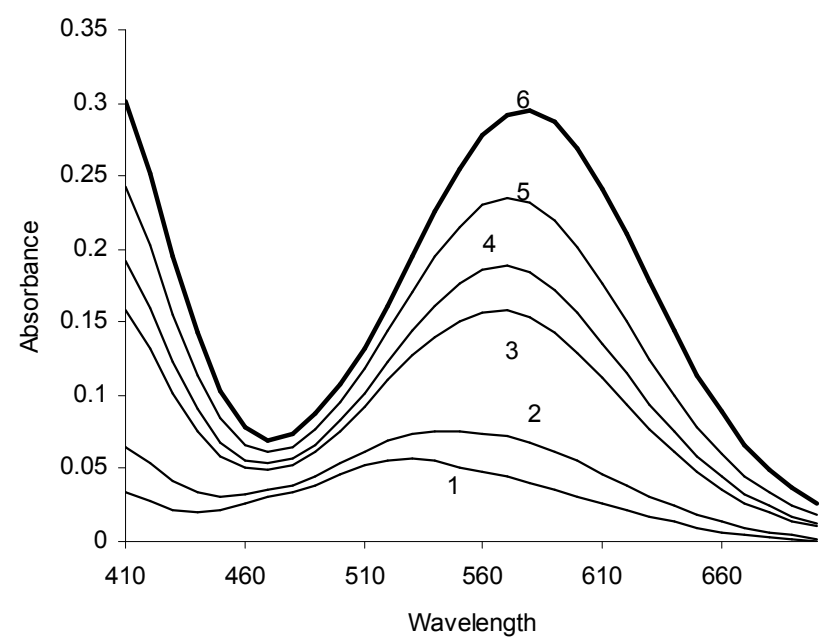

Figure 12. Change in absorbance as a function of time in the reaction between $\left[\mathrm{Co}^{\mathrm{II}}(\mathrm{NTA}) \mathrm{Val}\left(\mathrm{H}_{2} \mathrm{O}\right)_{2}\right]^{2-}$ and $\left[\mathrm{IO}_{4}\right]^{-}$. Curve (6) shows the spectra of the final cobalt (III) product.

Table 1. Values of molar absorptiviy $\varepsilon_{\max }$.

\begin{tabular}{|c|c|c|}
\hline$\left[\mathrm{Co}^{\mathrm{II}}\right]$ & $\begin{array}{l}\varepsilon_{\max }{ }^{308}=59 \\
\mathrm{dm}^{3} \mathrm{~mol}^{-1} \mathrm{~cm}^{-1}\end{array}$ & $\begin{array}{l}\varepsilon_{\max }^{510}=26 \\
\mathrm{dm}^{3} \mathrm{~mol}^{-1} \mathrm{~cm}^{-1} .\end{array}$ \\
\hline$\left[\mathrm{Co}^{\mathrm{II}}(\mathrm{NTA})\left(\mathrm{H}_{2} \mathrm{O}\right)\right]^{-}$ & $\begin{array}{l}\varepsilon_{\max }{ }^{314}=218 \\
\mathrm{dm}^{3} \mathrm{~mol}^{-1} \mathrm{~cm}^{-1}\end{array}$ & $\begin{array}{l}\varepsilon_{\max } 512=79 \\
\mathrm{dm}^{3} \mathrm{~mol}^{-1} \mathrm{~cm}^{-1} .\end{array}$ \\
\hline$\left[\mathrm{Co}^{\mathrm{II}}(\mathrm{NTA})(\mathrm{Asp})\left(\mathrm{H}_{2} \mathrm{O}\right)_{2}\right]^{-3}$ & $\begin{array}{l}\varepsilon_{\max }{ }^{308}=105 \\
\mathrm{dm}^{3} \mathrm{~mol}^{-1} \mathrm{~cm}^{-1}\end{array}$ & $\begin{array}{l}\varepsilon_{\max }^{512}=107 \\
\mathrm{dm}^{3} \mathrm{~mol}^{-1} \mathrm{~cm}^{-1} .\end{array}$ \\
\hline$\left[\mathrm{Co}^{\mathrm{III}}(\mathrm{NTA})(\mathrm{Val})\left(\mathrm{H}_{2} \mathrm{O}\right)_{2}\right]^{-2}$ & $\begin{array}{l}\varepsilon_{\max }{ }^{306}=79.67 \\
\mathrm{dm}^{3} \mathrm{~mol}^{-1} \mathrm{~cm}^{-1}\end{array}$ & $\begin{array}{l}\varepsilon_{\max }{ }^{512}=98.25 \\
\mathrm{dm}^{3} \mathrm{~mol}^{-1} \mathrm{~cm}^{-1} .\end{array}$ \\
\hline
\end{tabular}

\section{Results}

Kinetics of $\quad\left[\mathrm{Co}^{\mathrm{II}}(\mathrm{NTA}) \mathrm{Asp}\left(\mathrm{H}_{2} \mathrm{O}\right)_{2}\right]^{3-} \quad$ and $\left[\mathrm{Co}^{\mathrm{II}}(\mathrm{NTA}) \mathrm{Val}\left(\mathrm{H}_{2} \mathrm{O}\right)_{2}\right]^{2-}$

Oxidation of $\left[\mathrm{Co}^{\mathrm{II}}(\mathrm{NTA}) \mathrm{L}\left(\mathrm{H}_{2} \mathrm{O}\right)_{\mathrm{x}}\right]^{\mathrm{n}-}$ by $\left(\mathrm{IO}_{4}\right)^{-}$were studied over a $\left[\mathrm{H}^{+}\right]$range of $(1.05-28.20) \times 10^{-5} \mathrm{~mol} \mathrm{dm}^{-3}$, and ionic strength range of $0.30-0.60 \mathrm{~mol} \mathrm{dm}^{-3}$ at $25-45^{\circ} \mathrm{C}$ using various $\left(\mathrm{IO}_{4}\right)^{-}$and complex concentrations.

Plots of $\ln \left(\mathrm{A}_{\alpha}-\mathrm{A}_{\mathrm{t}}\right)$ versus time were linear up to $85 \%$ of reaction where $A_{t}$ and $A_{\alpha}$ are absorbance at time $t$, and infinity, respectively. Pseudo-first order rate constants, $\mathrm{k}_{\mathrm{obs}}$, obtained from the slopes of these plots, Table $(2 \& 3)$. These data show that, $\mathrm{k}_{\mathrm{obs}}$, was unaffected when the concentration of the $\mathrm{Co}^{\mathrm{II}}-$ complex was varied at constant $\left(\mathrm{IO}_{4}\right)^{-}$ concentration indicating first order dependence on the complex concentration.

$$
\left.\mathrm{d}\left[\mathrm{Co}^{\mathrm{III}}(\mathrm{NTA}) \mathrm{L}\left(\mathrm{H}_{2} \mathrm{O}\right)_{\mathrm{X}}\right]^{\mathrm{n}-} / \mathrm{dt}=\mathrm{k}_{\mathrm{obs}}\left[\mathrm{Co}^{\mathrm{II}}(\mathrm{NTA}) \mathrm{L}\left(\mathrm{H}_{2} \mathrm{O}\right)_{\mathrm{x}}\right]^{\mathrm{n}-}\right\}_{\mathrm{o}}
$$


Plots of $\mathrm{k}_{\mathrm{obs}}$ against $\left[\mathrm{IO}_{4}^{-}\right]$were found to be linear, (Figures 13 and 14). The dependence of $\mathrm{k}_{\mathrm{obs}}$ on $\left[\mathrm{IO}_{4}{ }^{-}\right]$, Table ( $\left.2 \& 3\right)$, is described by

$$
\mathrm{k}_{\mathrm{obs}}=\mathrm{k}_{1}\left[\mathrm{IO}_{4}^{-}\right]
$$

The kinetics of the reaction was studied over $\left[\mathrm{H}^{+}\right]$range $(1.05-28.20) \times 10^{-5} \mathrm{~mol} \mathrm{dm}^{-3}$ at different temperatures Table (4 \& 5) lists the variation of $\mathrm{k}_{1}$ with $\left[\mathrm{H}^{+}\right]$at different temperatures which indicate that the reaction rate increased gradually with decreasing $\left[\mathrm{H}^{+}\right]$. Plots of $\mathrm{k}_{1}$ versus $\left[\mathrm{H}^{+}\right]$were linear, with intercepts as shown in (Figures 15 and 16). This behavior can be described by equation 3 .

$$
\mathrm{k}_{1}=\mathrm{k}_{2}+\mathrm{k}_{3} /\left[\mathrm{H}^{+}\right]
$$

Values of $\mathrm{k}_{2}$ and $\mathrm{k}_{3}$ were calculated at different temperatures, and were listed in Table (6 \& 7).

The thermodynamic activation parameters were calculated by using the transition state theory equation. The enthalpies of activation, $\Delta \mathrm{H}^{*}{ }_{2}$ and $\Delta \mathrm{H}^{*}{ }_{3}$ for $\left[\mathrm{Co}(\mathrm{NTA}) \mathrm{Asp}\left(\mathrm{H}_{2} \mathrm{O}\right)_{2}\right]^{3-}$ were reported as $44.6 \pm 0.12$ and $76.9 \pm 0.18 \mathrm{kjmol}^{-1}$, respectively. The corresponding entropies of activation, $\Delta \mathrm{S}^{*}$ and $\Delta \mathrm{S}_{3}{ }_{3}$ were $-128.0 \pm 0.03$ and $-114.4 \pm 0.1 \mathrm{JK}^{-1} \mathrm{~mol}^{-1}$ respectively.

Also, The enthalpies of activation, $\Delta \mathrm{H}^{*}{ }_{2}$ and $\Delta \mathrm{H}^{*}{ }_{3}$ for $\left[\mathrm{Co}^{\mathrm{II}}(\mathrm{NTA}) \mathrm{Val}\left(\mathrm{H}_{2} \mathrm{O}\right)_{2}\right]^{2-}$ were reported as $49.1 \pm 0.12$ and $65.8 \pm 0.18 \mathrm{kjmol}^{-1}$, respectively. The corresponding entropies of activation, $\Delta \mathrm{S}^{*}$ and $\Delta \mathrm{S}_{3}$ were $-115.2 \pm 0.03$ and $-153.8 \pm 0.1 \mathrm{JK}^{-1} \mathrm{~mol}^{-1}$ respectively. Furthermore, the reaction rate increased with an increase in ionic strength, over a $0.30-0.60 \mathrm{~mol} \mathrm{dm}^{-3}$ range as shown in Table $(2,3)$.

From equations 1, 2 and 3 the experimental rate law was derived, as:

$$
\text { Rate }=\left(\mathrm{k}_{2}+\mathrm{k}_{3} /\left[\mathrm{H}^{+}\right]\right)\left\{\left[\mathrm{Co}^{\mathrm{II}}(\mathrm{NTA}) \mathrm{L}\left(\mathrm{H}_{2} \mathrm{O}\right)_{\mathrm{x}}\right]^{\mathrm{n}-}\right\}_{\mathrm{o}}\left[\mathrm{IO}_{4}^{-}\right]
$$

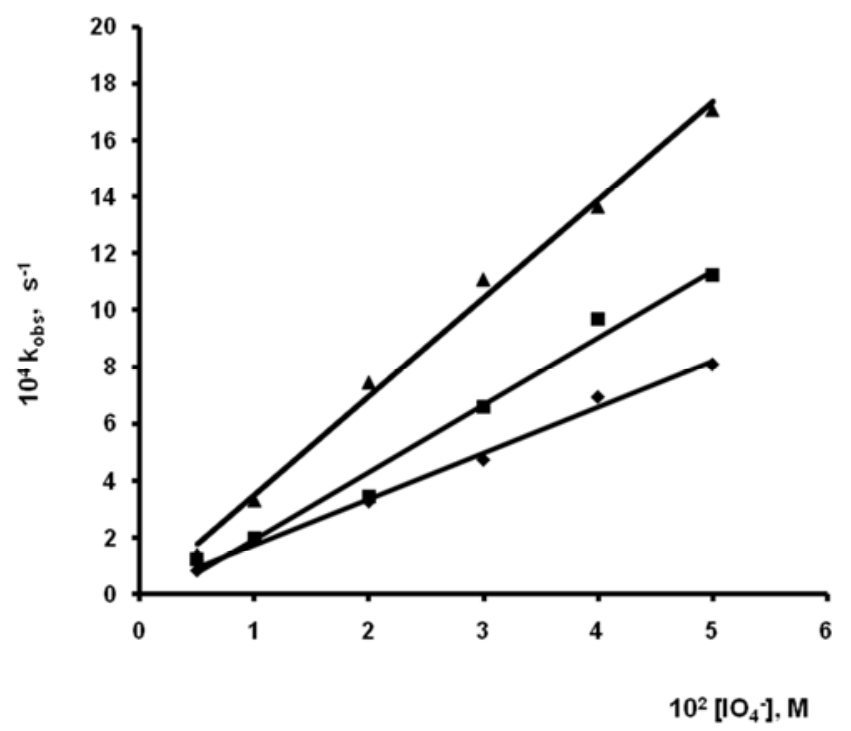

Figure 13. Variation of $k_{o b s}$ versus $\left[\mathrm{IO}_{4}\right]^{-}$at different temperature for oxidation of $\left[\mathrm{Co}^{I I}(\mathrm{NTA}) \mathrm{Asp}\left(\mathrm{H}_{2} \mathrm{O}\right)_{2}\right]^{3-}$.

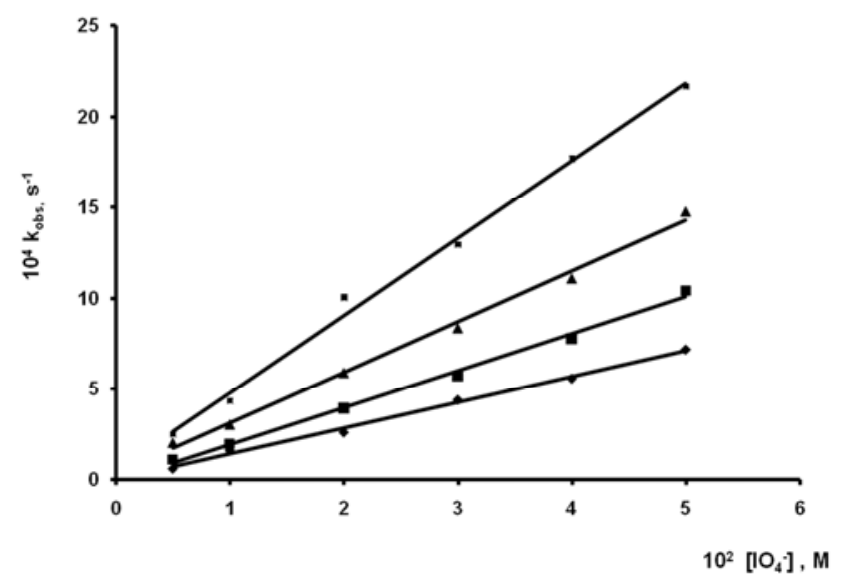

Figure 14. Variation of $k_{\text {obs }}$ versus $\left[\mathrm{IO}_{4}\right]^{-}$at different temperature for oxidation of $\left[\mathrm{Co}^{\mathrm{II}}(\mathrm{NTA}) \operatorname{Val}\left(\mathrm{H}_{2} \mathrm{O}\right)_{2}\right]^{2-}$.

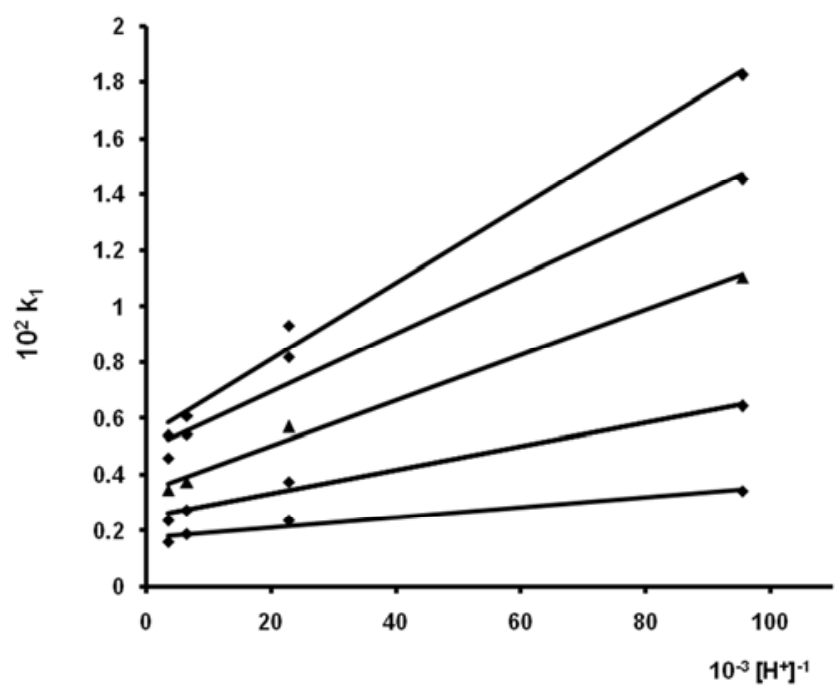

Figure 15. Variation of $k_{1}$ on $\left[\mathrm{H}^{+}\right]$for oxidation of $\left[\mathrm{Co}^{\mathrm{II}}(\mathrm{NTA}) \mathrm{Asp}\left(\mathrm{H}_{2} \mathrm{O}\right)_{2}\right]^{3-}$.

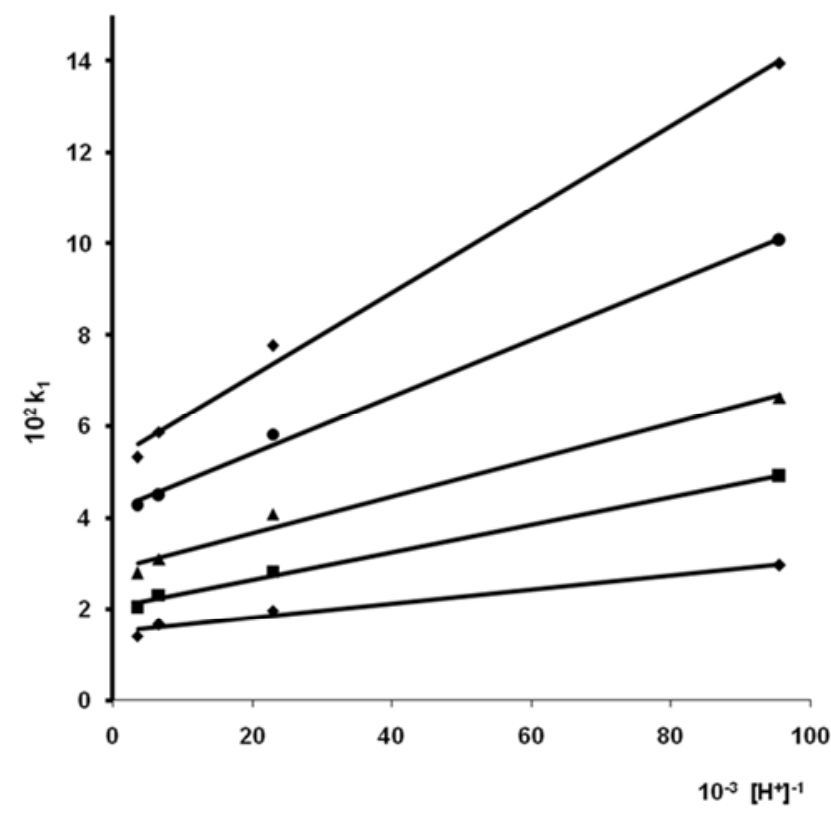

Figure 16. Variation of $k_{1}$ on $\left[\mathrm{H}^{+}\right]$for oxidation of $\left[\mathrm{Co}^{\mathrm{II}}(\mathrm{NTA}) \mathrm{Val}\left(\mathrm{H}_{2} \mathrm{O}\right)_{2}\right]^{2-}$. 
Table 2. Dependence of the reaction rate constant, $10^{4} \mathrm{kbbs}^{-1}$, on $\left[\mathrm{Co}^{I I}(\mathrm{NTA}) \mathrm{Asp}\left(\mathrm{H}_{2} \mathrm{O}\right)_{2}\right]^{3-a}$, [IO $\left.{ }_{4}^{-}\right], I^{b}$ and temperatures at $\left[\mathrm{H}^{+}\right]=28.2 \times 10^{-5} \mathrm{~mol} \mathrm{dm}^{-3}$.

\begin{tabular}{|c|c|c|c|}
\hline \multirow{2}{*}{$10^{2}\left[\mathrm{IO}_{4}^{-}\right], \mathrm{M}$} & \multicolumn{3}{|l|}{$10^{4} k_{\text {obs }}, s^{-1}$} \\
\hline & $T=25^{\circ}$ & $T=30^{\circ}$ & $T=35^{\circ}$ \\
\hline 5.0 & $8.08 \pm 0.04$ & $11.23 \pm 0.03$ & $17.05 \pm 0.02$ \\
\hline 4.0 & $6.93 \pm 0.03$ & $9.68 \pm 0.04$ & $13.63 \pm 0.01$ \\
\hline 3.0 & $4.73 \pm 0.01$ & $6.57 \pm 0.03$ & $11.07 \pm 0.01$ \\
\hline 2.0 & $3.27 \pm 0.02$ & $3.43 \pm 0.02$ & $7.43 \pm 0.03$ \\
\hline 1.0 & $1.97 \pm 0.02$ & $1.93 \pm 0.02$ & $3.30 \pm 0.02$ \\
\hline 0.5 & $0.83 \pm 0.02$ & $1.22 \pm 0.12$ & $1.41 \pm 0.01$ \\
\hline
\end{tabular}

${ }^{\mathrm{a}}\left[\mathrm{Co}(\mathrm{NTA}) \operatorname{Asp}\left(\mathrm{H}_{2} \mathrm{O}\right)_{2}\right]^{3-}=2.0 \times 10^{-3} \mathrm{~mol} \mathrm{dm}^{-3} ; \mathrm{I}^{\mathrm{b}}=0.25 \mathrm{~mol} \mathrm{dm}^{-3}$.

at $10^{3-}\left[\mathrm{Co}^{\mathrm{II}}(\mathrm{NTA}) \operatorname{Asp}\left(\mathrm{H}_{2} \mathrm{O}\right)_{2}\right]^{3-}=0.5,1.0,3.0$ and $4.0 \mathrm{~mol} \mathrm{dm}^{-3}, 35^{\circ} \mathrm{C}, \mathrm{I}^{\mathrm{b}}$,

$\left[\mathrm{IO}_{4}{ }^{-}\right]=0.02 \mathrm{moldm}^{-3}$, and $\left[\mathrm{H}^{+}\right]=4.36 \times 10^{-5} \mathrm{~mol} \mathrm{dm}^{-3}$

$10^{4} k_{\mathrm{obs}}=\{14.3,15.1,12.6$ and 14.2$\} \mathrm{s}^{-1}$, respectively. While at $(\mathrm{I})=0.3,0.4,0.5$, and $\left.0.6 \mathrm{~mol} \mathrm{dm}^{-3}, 35^{\circ} \mathrm{C},{ }^{\mathrm{a}}\left[\mathrm{Co}^{\mathrm{II}}(\mathrm{NTA}) \mathrm{Asp}\left(\mathrm{H}_{2} \mathrm{O}\right)_{2}\right]^{3-}, \mathrm{IO}_{4}^{-}\right]=0.02 \mathrm{~mol} \mathrm{dm}^{-3}$, an0d $\left[\mathrm{H}^{+}\right]=4.36 \times 10^{-5} \mathrm{~mol} \mathrm{dm}^{-3} 10^{4} \mathrm{k}_{\mathrm{obs}}=\{18.36,26.20,29.01$ and 36.11$\} \mathrm{s}^{-1}$, respectively

Table 3. Variation of the reaction rate constant, $10^{4} k_{o b s} s^{-1}$, on ${ }^{a}\left[\mathrm{Co}^{I I}(\mathrm{NTA}) \text { Val }\left(\mathrm{H}_{2} \mathrm{O}\right)_{2}\right]^{2-},\left[\mathrm{IO}_{4}^{-}\right], \mathrm{I}^{\text {b }}$ at temperatures at $\left[\mathrm{H}^{+}\right]=28.2 \times 10^{-5} \mathrm{~mol} \mathrm{dm}^{-}$.

\begin{tabular}{llll}
\hline \multirow{2}{*}{$\mathbf{1 0}^{2}\left[\mathbf{I O}_{4}{ }^{-}\right], \mathbf{M}$} & $\mathbf{1 0}^{\mathbf{4}} \mathbf{k}_{\text {obs }}, \mathbf{s}^{-\mathbf{1}}$ & $\mathbf{T}=\mathbf{3 0}^{\mathbf{0}}$ & $\mathbf{T}=\mathbf{4 5}^{\mathbf{0}}$ \\
\cline { 2 - 4 } & $\mathbf{T}=\mathbf{2 5}^{\mathbf{0}}$ & $8.34 \pm 0.011$ & $27.67 \pm 0.010$ \\
5.0 & $7.18 \pm 0.011$ & $7.20 \pm 0.012$ & $20.57 \pm 0.014$ \\
4.0 & $5.58 \pm 0.012$ & $5.12 \pm 0.011$ & $12.82 \pm 0.013$ \\
3.0 & $4.40 \pm 0.015$ & $3.43 \pm 0.015$ & $5.78 \pm 0.004$ \\
2.0 & $2.62 \pm 0.017$ & $1.97 \pm 0.012$ & $3.42 \pm 0.010$ \\
1.0 & $1.60 \pm 0.010$ & $0.95 \pm 0.10$ & \\
0.5 & $0.69 \pm 0.021$ & & \\
\hline
\end{tabular}

${ }^{\mathrm{a}}\left[\mathrm{Co}^{\mathrm{II}}(\mathrm{NTA}) \mathrm{Val}\left(\mathrm{H}_{2} \mathrm{O}\right)_{2}\right]^{2-}=2.0 \times 10^{-3} \mathrm{~mol} \mathrm{dm}^{-3} ; \mathrm{I}^{\mathrm{b}}=0.25 \mathrm{~mol} \mathrm{dm}^{-3}$.

at $10^{3-}\left[\mathrm{Co}^{\mathrm{II}}(\mathrm{NTA}) \mathrm{Val}\left(\mathrm{H}_{2} \mathrm{O}\right)_{2}\right]^{2-}=0.5,1.0,3.0$ and $4.0 \mathrm{~mol} \mathrm{dm}^{-3}, 35^{\circ} \mathrm{C}, \mathrm{I}^{\mathrm{b}}$,

$\left[\mathrm{IO}_{4}{ }^{-}\right]=0.02 \mathrm{moldm}^{-3}$, and $\left[\mathrm{H}^{+}\right]=4.36 \times 10^{-5} \mathrm{~mol} \mathrm{dm}^{-3}$

$10^{4} k_{\text {obs }}=\{11.4,12.1,12.6$ and 11.2$\} \mathrm{s}^{-1}$, respectively. While at $(\mathrm{I})=0.3,0.4,0.5$, and $\left.0.6 \mathrm{~mol} \mathrm{dm}^{-3}, 35^{\circ} \mathrm{C},{ }^{\mathrm{a}}\left[\mathrm{Co}^{\mathrm{II}}(\mathrm{NTA}) \mathrm{Val}\left(\mathrm{H}_{2} \mathrm{O}\right)_{2}\right]^{2-}, \mathrm{IO}_{4}{ }^{-}\right]=0.02 \mathrm{~mol} \mathrm{dm}^{-3}, a^{2}$ $\left[\mathrm{H}^{+}\right]=4.36 \times 10^{-5} \mathrm{~mol} \mathrm{dm}^{-3} 10^{4} \mathrm{k}_{\mathrm{obs}}=\{11.16,13.25,20.01$ and 24.14$\} \mathrm{s}^{-1}$ respectively

Table 4. Variation of $k_{l}$ with $\left[\mathrm{H}^{+}\right]$at $\left[\mathrm{CO}^{\mathrm{II}}(\mathrm{NTA}) \mathrm{Asp}\left(\mathrm{H}_{2} \mathrm{O}\right)_{2}\right]^{3-}=2.0 \times 10^{-3} \mathrm{~mol} \mathrm{dm}^{-3}, I=0.25 \mathrm{~mol} \mathrm{dm^{-3 }}$, different $\left[\mathrm{IO}_{4}^{-}\right]$and different temperatures.

\begin{tabular}{llllll}
\hline $\mathbf{1 0 5}[\mathbf{H}+]$ & $\mathbf{1 0 2} \mathbf{~ k 1}, \mathbf{M}-\mathbf{1 s}-\mathbf{1})$ & & & $\mathbf{T}=\mathbf{4 0}^{\mathbf{0}}$ & $\mathbf{T}_{\mathbf{4}} \mathbf{4 5}^{\mathbf{0}}$ \\
\cline { 2 - 6 } $\mathbf{m o l ~ d m}^{-3}$ & $\mathbf{T}=\mathbf{2 5}^{\mathbf{0}}$ & $\mathbf{T}=\mathbf{3 0}^{\mathbf{0}}$ & $\mathbf{T}=\mathbf{3 5}^{\mathbf{0}}$ & $4.61 \pm 0.03$ & $5.38 \pm 0.05$ \\
\hline 28.2 & $1.61 \pm 0.09$ & $2.37 \pm 0.01$ & $3.12 \pm 0.09$ & $5.45 \pm 0.04$ & $6.10 \pm 0.06$ \\
15.1 & $1.90 \pm 0.01$ & $2.72 \pm 0.02$ & $3.75 \pm 0.03$ & $8.20 \pm 0.05$ & $9.32 \pm 0.07$ \\
4.36 & $2.39 \pm 0.01$ & $3.74 \pm 0.02$ & $5.71 \pm 0.03$ & $14.54 \pm 0.06$ & $18.26 \pm 0.08$ \\
1.05 & $3.42 \pm 0.03$ & $6.43 \pm 0.03$ & $11.05 \pm 0.04$ & \\
\hline
\end{tabular}

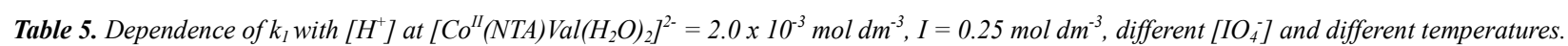

\begin{tabular}{|c|c|c|c|c|c|}
\hline \multirow{2}{*}{$\begin{array}{l}10^{5}\left[\mathrm{H}^{+}\right] \\
\mathrm{mol} \mathbf{d m}^{-3}\end{array}$} & \multicolumn{5}{|c|}{$10^{2} k_{1},\left(M^{-1} s^{-1}\right)$} \\
\hline & $\mathbf{T}=\mathbf{2 5}^{\circ}$ & $\mathbf{T}=\mathbf{3 0}^{\circ}$ & $\mathbf{T}=\mathbf{3 5}^{\circ}$ & $T=40^{\circ}$ & $T=\mathbf{4 5}^{\circ}$ \\
\hline 28.2 & $1.43 \pm 0.06$ & $2.03 \pm 0.04$ & $2.79 \pm 0.03$ & $4.26 \pm 0.02$ & $5.31 \pm 0.03$ \\
\hline 15.1 & $1.68 \pm 0.01$ & $2.31 \pm 0.02$ & $3.09 \pm 0.02$ & $4.48 \pm 0.03$ & $5.87 \pm 0.03$ \\
\hline 4.36 & $1.97 \pm 0.01$ & $2.83 \pm 0.02$ & $4.08 \pm 0.03$ & $5.82 \pm 0.05$ & $7.76 \pm 0.04$ \\
\hline 1.05 & $2.96 \pm 0.03$ & $4.90 \pm 0.03$ & $6.62 \pm 0.02$ & $10.07 \pm 0.06$ & $13.94 \pm 0.07$ \\
\hline
\end{tabular}

Table 6. Variation of $k_{2}$ and $k_{3}$ with temperatures at $\left[\mathrm{Co}^{I I}(\mathrm{NTA}) \mathrm{Asp}\left(\mathrm{H}_{2} \mathrm{O}\right)_{2}\right]^{3-}=2.0 \times 10^{-3} \mathrm{~mol} \mathrm{dm^{-3 }}, \mathrm{I}=0.25 \mathrm{~mol} \mathrm{dm}^{-3}$, different $\left[\mathrm{IO}_{4}^{-}\right]$and different $\left[\mathrm{H}^{+}\right]$.

\begin{tabular}{lll}
\hline $\mathbf{T},{ }^{\circ} \mathbf{C}$ & $\mathbf{1 0}^{\mathbf{3}} \mathbf{k}_{\mathbf{2}}, \mathbf{M}^{-1} \mathbf{s}^{-1}$ & $\mathbf{1 0}^{\mathbf{7}} \mathbf{k}_{\mathbf{3}}, \mathbf{s}^{-1}$ \\
\hline 25 & $17.52 \pm 0.015$ & $1.81 \pm 0.010$ \\
30 & $24.63 \pm 0.030$ & $4.20 \pm 0.009$ \\
35 & $32.40 \pm 0.034$ & $8.30 \pm 0.010$ \\
40 & $48.84 \pm 0.050$ & $10.30 \pm 0.013$ \\
45 & $54.04 \pm 0.065$ & $13.70 \pm 0.017$ \\
\hline
\end{tabular}

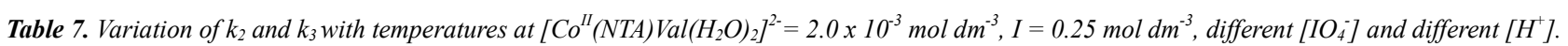

\begin{tabular}{lll}
\hline $\mathbf{T},{ }^{\circ} \mathbf{C}$ & $\mathbf{1 0}^{\mathbf{3}} \mathbf{k}_{\mathbf{2}}, \mathbf{M}^{\mathbf{- 1}} \mathbf{s}^{-\mathbf{1}}$ & $\mathbf{1 0}^{\mathbf{7}} \mathbf{k}_{\mathbf{3}}, \mathbf{s}^{-\mathbf{1}}$ \\
\hline 25 & $15.01 \pm 0.013$ & $1.56 \pm 0.014$ \\
30 & $20.53 \pm 0.020$ & $3.00 \pm 0.019$ \\
35 & $28.59 \pm 0.031$ & $4.00 \pm 0.012$ \\
40 & $41.49 \pm 0.040$ & $6.25 \pm 0.023$ \\
45 & $52.78 \pm 0.055$ & $9.15 \pm 0.019$ \\
\hline
\end{tabular}




\section{Discussion}

The lability of cobalt(II) reactants and the inertness of cobalt(III) products could be utilized as a diagnostic tool for ascertaining inner-sphere electron transfer [10, 13-15]. Oxidation of some cobalt(II) complexes by periodate, where an initial cobalt (III) product was observed, was interpreted in terms of this mechanism.

An inner-sphere mechanism is proposed for the bath way of oxidation of both two $\mathrm{Co}^{\mathrm{II}}$ complexes $\left.\mathrm{Co}^{\mathrm{II}}(\mathrm{NTA}) \mathrm{Asp}\left(\mathrm{H}_{2} \mathrm{O}\right)_{2}\right]^{3-}$ and $\left[\mathrm{Co}^{\mathrm{II}}(\mathrm{NTA}) \operatorname{Val}\left(\mathrm{H}_{2} \mathrm{O}\right)_{2}\right]^{2-}$,. This proposal seems to be supported for the following reasons:

- Formation of the initial cobalt (III) products, which were slowly converted to the final cobalt products [13, 15, 24].

- Periodate ion is capable of acting as a ligand, as evidenced from its coordination to copper(III) [25] and nickel [26].

In aqueous acidic medium the $\left.\mathrm{Co}^{\mathrm{II}}(\mathrm{NTA}) \mathrm{Asp}\left(\mathrm{H}_{2} \mathrm{O}\right)_{2}\right]^{3-}$ and $\left[\mathrm{Co}^{\mathrm{II}}(\mathrm{NTA}) \mathrm{Val}\left(\mathrm{H}_{2} \mathrm{O}\right)_{2}\right]^{2-}$, complexes are in equilibria:

$$
\begin{gathered}
\left.\mathrm{Co}^{\mathrm{II}}(\mathrm{NTA}) \operatorname{Asp}\left(\mathrm{H}_{2} \mathrm{O}\right)_{2}\right]^{3-} \rightleftharpoons \\
{\left[\mathrm{Co}^{\mathrm{II}}(\mathrm{NTA}) \operatorname{Asp}(\mathrm{OH})\left(\mathrm{H}_{2} \mathrm{O}\right)\right]^{4-}+\mathrm{H}^{+} \mathrm{K}_{1}} \\
\left.\mathrm{Co}^{\mathrm{II}}(\mathrm{NTA}) \operatorname{Val}\left(\mathrm{H}_{2} \mathrm{O}\right)_{2}\right]^{2-} \rightleftharpoons \\
{\left[\mathrm{Co}^{\mathrm{II}}(\mathrm{NTA}) \operatorname{Val}(\mathrm{OH})\left(\mathrm{H}_{2} \mathrm{O}\right)\right]^{3-}+\mathrm{H}^{+} \mathrm{K}_{2}}
\end{gathered}
$$

$\mathrm{K}_{1}$ and $\mathrm{K}_{2}$ were potentiometrically determined as $1.38 \mathrm{x}$ $10^{-6}$ and $5.01 \times 10^{-7}$, respectively. It was observed from values of $\mathrm{K}_{1}$ and $\mathrm{K}_{2}$ at the employed $\mathrm{pH}$ range that these equilibriums were not prevailing and the protonated $\mathrm{Co}^{\mathrm{II}}$ complex species was the predominant.

In aqueous solutions, periodate species are found in the equilibria [27].

$$
\begin{gathered}
\mathrm{H}_{5} \mathrm{IO}_{6} \rightleftharpoons \mathrm{H}_{4} \mathrm{IO}_{6}^{-}+\mathrm{H}^{+}\left(\mathrm{K}_{3}=1.0 \times 10^{-3}\right. \\
\mathrm{H}_{4} \mathrm{IO}_{6}^{-} \rightleftharpoons 2 \mathrm{H}_{2} \mathrm{O}+\mathrm{IO}_{4}^{-}\left(\mathrm{K}_{4}=43\right) \\
\mathrm{H}_{4} \mathrm{IO}_{6}^{-} \rightleftharpoons \mathrm{H}_{3} \mathrm{IO}_{6}{ }^{2-}+\mathrm{H}^{+}\left(\mathrm{K}_{5}=5.0 \times 10^{-6}\right)
\end{gathered}
$$

Thus, it may be concluded that over the $\left[\mathrm{H}^{+}\right]$range used, the periodate species likely to be present are $\mathrm{H}_{5} \mathrm{IO}_{6}$ and $\mathrm{H}_{4} \mathrm{IO}_{6}{ }^{-}$.

The hydrogen ion dependence of the reaction rate of both complexes is in agreement with the involvement of both deprotonated and protonated forms of periodate in the rate determining steps, proceeded by a rapid deprotonation equilibrium and in which both forms are reactive.

The concomitant reaction rate increase with the increase of ionic strength may be attributed to that the reaction rate, in the rate determining step, occurred between two species of the same sign.

In view of the above considerations, kinetics of oxidation of $\left[\mathrm{Co}^{\mathrm{II}}(\mathrm{NTA}) \mathrm{L}\left(\mathrm{H}_{2} \mathrm{O}\right)_{\mathrm{x}}\right]^{-\mathrm{n}}$ by periodate proceeds by one first order pathway in each reactant.

The mechanism could be described by the following equations (10-14).

$$
\begin{gathered}
\mathrm{H}_{5} \mathrm{IO}_{6} \rightleftharpoons \mathrm{H}_{4} \mathrm{IO}_{6}^{-}+\mathrm{H}^{+} \mathrm{K}_{3}(11)\left[\mathrm{Co}^{\mathrm{II}}(\mathrm{NTA}) \mathrm{L}\left(\mathrm{H}_{2} \mathrm{O}\right)_{\mathrm{x}}\right]^{-\mathrm{n}}+ \\
\mathrm{H}_{5} \mathrm{IO}_{6} \rightleftharpoons \\
{\left[\mathrm{Co}^{\mathrm{II}}(\mathrm{NTA}) \mathrm{L}\left(\mathrm{H}_{5} \mathrm{IO}_{6}\right)\left(\mathrm{H}_{2} \mathrm{O}\right)_{\mathrm{X}-1]}{ }^{-\mathrm{n}}+\mathrm{H}_{2} \mathrm{O} \mathrm{K} \mathrm{K}_{6}(10)\right.} \\
{\left[\mathrm{Co}^{\mathrm{II}}(\mathrm{NTA}) \mathrm{L}\left(\mathrm{H}_{2} \mathrm{O}\right)_{\mathrm{x}}\right]^{-\mathrm{n}}+\mathrm{H}_{4} \mathrm{IO}_{6}^{-} \rightleftharpoons} \\
{\left[\mathrm{Co}^{\mathrm{II}}(\mathrm{NTA}) \mathrm{L}\left(\mathrm{H}_{4} \mathrm{IO}_{6}\right)\left(\mathrm{H}_{2} \mathrm{O}\right)_{\mathrm{X}-1]^{-(\mathrm{n}+1)}+\mathrm{H}_{2} \mathrm{O} \mathrm{K}}\right.} \\
{\left[\mathrm{Co}^{\mathrm{II}}(\mathrm{NTA}) \mathrm{L}\left(\mathrm{H}_{5} \mathrm{IO}_{6}\right)\left(\mathrm{H}_{2} \mathrm{O}\right)_{\mathrm{X}-1]}{ }^{-\mathrm{n}} \rightarrow\right.} \\
{\left[\mathrm{Co}^{\mathrm{III}}(\mathrm{NTA}) \mathrm{L}\left(\mathrm{H}_{5} \mathrm{IO}_{6}\right)\left(\mathrm{H}_{2} \mathrm{O}\right)_{\mathrm{X}-1}\right]^{(-\mathrm{n}+1)} \mathrm{k}_{10}} \\
{\left[\mathrm{Co}^{\mathrm{II}}(\mathrm{NTA}) \mathrm{L}\left(\mathrm{H}_{4} \mathrm{IO}_{6}\right)\left(\mathrm{H}_{2} \mathrm{O}\right)_{\mathrm{X}-1}\right]^{-(\mathrm{n}+1)} \rightarrow} \\
{\left[\mathrm{Co}^{\mathrm{III}}(\mathrm{NTA}) \mathrm{L}\left(\mathrm{H}_{4} \mathrm{IO}_{6}\right)\left(\mathrm{H}_{2} \mathrm{O}\right)_{\mathrm{X}-1]}{ }^{-(\mathrm{n}+2)} \mathrm{k}_{11}\right.}
\end{gathered}
$$

From the above mechanism, the rate of the reaction can be described by Equation (14),

$$
\begin{aligned}
\text { Rate } & \left.=\mathrm{k}_{10} \mathrm{~K}_{6}\left[\mathrm{Co}^{\mathrm{II}}(\mathrm{NTA}) \mathrm{L}\left(\mathrm{H}_{2} \mathrm{O}\right)_{\mathrm{x}}\right)^{-\mathrm{n}}\right]\left[\mathrm{H}_{5} \mathrm{IO}_{6}\right] \\
& \left.+\mathrm{k}_{11} \mathrm{~K}_{7}\left[\mathrm{Co}^{\mathrm{II}}(\mathrm{NTA}) \mathrm{L}\left(\mathrm{H}_{2} \mathrm{O}\right)_{\mathrm{x}}\right)^{-\mathrm{n}}\right]\left[\mathrm{H}_{4} \mathrm{IO}_{6}^{-}\right]
\end{aligned}
$$

Substituting $\left[\mathrm{H}_{4} \mathrm{IO}_{6}^{-}\right]$from equation (7) gives,

$$
\begin{gathered}
\text { Rate } \left.=\left[\mathrm{Co}^{\mathrm{II}}(\mathrm{NTA}) \mathrm{L}\left(\mathrm{H}_{2} \mathrm{O}\right)_{\mathrm{x}}\right)^{-\mathrm{n}}\right]\left[\mathrm{H}_{5} \mathrm{IO}_{6}\right] \\
\left\{\mathrm{k}_{10} \mathrm{~K}_{6}+\left(\mathrm{k}_{11} \mathrm{~K}_{7} \mathrm{~K}_{3} /\left[\mathrm{H}^{+}\right)\right\}\right.
\end{gathered}
$$

Which is identical to the experimental rate law, Equation (4), and therefore,

$$
\mathrm{k}_{\mathrm{obs}}=\left\{\mathrm{k}_{10} \mathrm{~K}_{6}+\left(\mathrm{k}_{11} \mathrm{~K}_{7} \mathrm{~K}_{3} /\left[\mathrm{H}^{+}\right]\right)\right\}\left[\mathrm{H}_{5} \mathrm{IO}_{6}\right]
$$

Comparison Equations (16) and (2), gives

$$
\mathrm{k}_{1}=\mathrm{k}_{10} \mathrm{~K}_{6}+\left(\mathrm{k}_{11} \mathrm{~K}_{7} \mathrm{~K}_{3} /\left[\mathrm{H}^{+}\right]\right)
$$

Values of $\mathrm{k}_{2}$ and $\mathrm{k}_{3}$ were obtained by comparison of Equations (17) and (3), as follows:

$$
\mathrm{k}_{2}=\mathrm{k}_{10} \mathrm{~K}_{6} \text { and } \mathrm{k}_{3}=\left(\mathrm{k}_{11} \mathrm{~K}_{7} \mathrm{~K}_{3}\right)
$$

The initial cobalt(III) product of oxidation of $\left.\left[\mathrm{Co}{ }^{\mathrm{II}}(\mathrm{NTA}) \mathrm{L}\left(\mathrm{H}_{2} \mathrm{O}\right)_{\mathrm{x}}\right)^{-\mathrm{n}}\right]$ by $\mathrm{IO}_{4}^{-}$may be converted to final products according to the equation (18),

$$
\left[\mathrm{NTA}(\mathrm{L}) \mathrm{Co}^{\mathrm{III}}-\mathrm{OIO}_{3}\right]^{-\mathrm{n}}+\mathrm{x} \mathrm{H}_{2} \mathrm{O} \rightarrow\left[\mathrm{Co}^{\mathrm{III}} \mathrm{NTA}(\mathrm{L})\left(\mathrm{H}_{2} \mathrm{O}\right)_{\mathrm{x}}\right]^{-\mathrm{n}}+\mathrm{I}^{\mathrm{VI}}(18)
$$

Then fast reaction takes place between $\mathrm{I}^{\mathrm{VI}}$ radicals,

$$
2 \mathrm{I}^{\mathrm{VI}} \rightarrow \mathrm{IO}_{4}^{-}+\mathrm{IO}_{3}^{-}
$$

In comparison, using cyclic voltammetric measurements, $\left.\mathrm{Co}^{\mathrm{II}}(\mathrm{NTA}) \mathrm{Asp}\left(\mathrm{H}_{2} \mathrm{O}\right)_{2}\right]^{3-}$ is difficulty oxidized at more positive potential, $+478 \mathrm{mV} v s$. SCE. While in the case of $\left[\mathrm{Co}^{\mathrm{II}}(\mathrm{NTA}) \mathrm{Val}\left(\mathrm{H}_{2} \mathrm{O}\right)_{2}\right]^{2-}$ the complex is more easy oxidized at less positive potential, $+179 \mathrm{mV} v s$. SCE. Thus the sequence of stability is Asp > Val. Complexes.

According to crystal field theory, $\mathrm{Co}^{+2}$ has $\mathrm{d}^{7}$ distributed as $\left(t_{2 g}\right)^{6}$ and $\left(e_{g}\right)^{1}$. Increase of crystal field energy $\Delta_{o}$ between $t_{2 g}$ and $e_{g}$ orbital, by strong field ligands, labilize the free electron in $\mathrm{e}_{\mathrm{g}}$. Values of $\mathrm{pK}_{\mathrm{a}}$ for valine and aspartic acid are 
2.3 and 1.88 respectively, i.e. strength of conjugate bases are in the sequence Asp $>$ Val. Therefore $\Delta_{o}$ for aspartate ligand is more than both valinate. Thus, loss of $e_{g}$ electron from the central $\mathrm{Co}^{+2}$ ion is easier in case of $\left[\mathrm{Co}^{\mathrm{II}}(\mathrm{NTA}) \mathrm{Val}\left(\mathrm{H}_{2} \mathrm{O}\right)_{2}\right]^{2-}$ than $\left.\mathrm{Co}^{\mathrm{II}}(\mathrm{NTA}) \mathrm{Asp}\left(\mathrm{H}_{2} \mathrm{O}\right)_{2}\right]^{3-}$. This is consistent with the order of stability of these complexes.

The high negative entropies of activation for this reaction were climbed to be largely the result of the charge concentration on encounter complex formation, which causes substantial mutual ordering of the solvated water molecules [28]. The intramolecular electron transfer steps are endothermic as indicated by the value of $\Delta \mathrm{H}^{*}$. The contributions of $\Delta \mathrm{H}^{*}$ and $\Delta \mathrm{S}^{*}$ to the rate constant seem to compensate each other. This fact suggests that the factors controlling $\Delta \mathrm{H}^{*}$ must be closely related to those controlling $\Delta \mathrm{S}^{*}$. Therefore, the solvation state of the encounter complex would be important in determining $\Delta \mathrm{H}$. Thus, the relatively small enthalpy of activation, $\Delta \mathrm{H}^{*}$, can be explained in terms of the formation of more solvated complex [29].

Oxidation of $\mathrm{Co}^{\mathrm{II}}$ complexes shows the formation of an initial $\mathrm{Co}^{\mathrm{III}}$ product. This may be due to the oxidation process being inner sphere. This is consistent with inner sphere oxidation which is generally proposed for $\mathrm{IO}_{4}^{-}$reactions. Through transformation of initial to final $\mathrm{Co}^{\mathrm{III}}$ product an $\mathrm{I}^{\mathrm{VI}}$ in the initial product is probably substituted by a water molecule with a slow rate due to inertness of $\mathrm{Co}^{\mathrm{III}}$ and $\mathrm{Co}^{\mathrm{II}}$ $\mathrm{OIO}_{3}$ bond is being stronger than $\mathrm{Co}-\mathrm{H}_{2} \mathrm{O}$ bond.

\section{Conclusion}

Ternary Co ${ }^{\text {II }}$ complexes involving NTA and the secondary ligand Valin and Aspartic acid are prepared and their structures were confirmed by different methods.

From the kinetic studies on the oxidation of $\left[\mathrm{Co}^{\mathrm{II}}(\mathrm{NTA})(\mathrm{Val})\left(\mathrm{H}_{2} \mathrm{O}\right)_{2}{ }^{-2}\right]$ and $\left[\mathrm{Co}^{\mathrm{II}}(\mathrm{NTA})(\mathrm{Asp})\left(\mathrm{H}_{2} \mathrm{O}\right)\right]^{-3}$ by periodate, the following results are concluded:-

(1)-The presence of $1 /[\mathrm{H}+]$ dependence in the acid medium of the reaction and the rate law suggests involving of the deprotonated form of the cobalt (II) complexes is the reactive species.

(2)-The using of $\mathrm{Mn}^{++}$as a catalyst in the reaction mixture is responsible for the oxidation of the complexes.

(3)-Oxidation of $\left.\mathrm{Co}^{\mathrm{II}}(\mathrm{NTA})(\mathrm{Val})\left(\mathrm{H}_{2} \mathrm{O}\right)_{2}{ }^{-2}\right]$ and $\left[\mathrm{Co}^{\mathrm{II}}\right.$ $\left.(\mathrm{NTA})(\mathrm{Asp})\left(\mathrm{H}_{2} \mathrm{O}\right)\right]^{-3}$ is a first -order reaction with respect to $\left[\mathrm{Co}^{\mathrm{II}} \text { (NTA)(Asp) }\left(\mathrm{H}_{2} \mathrm{O}\right)\right]^{-3}$.

(4)-The rate of oxidation of $\left[\mathrm{Co}^{\mathrm{II}}(\mathrm{NTA})(\mathrm{Asp})\left(\mathrm{H}_{2} \mathrm{O}\right)\right]^{-3}$ is faster than $\left[\mathrm{Co}^{\mathrm{II}}(\mathrm{NTA})(\mathrm{Val})\left(\mathrm{H}_{2} \mathrm{O}\right)_{2}^{-2}\right]$ as evidenced from values of electron transfer rate constant for the two complexes.

(5)-The high negative entropies of activation for which reaction were climbed to be largely the result of the charge concentration on the formed encounter complex, which causes substantial mutual ordering of the solvent molecules of the solvated complex. The intramolecular electron transfer steps are endothermic as indicated by the value of $\Delta \mathrm{H}^{*}$.

The contributions of $\Delta \mathrm{H}^{*}$ and $\Delta \mathrm{S}^{*}$ to the rate constant seem to compensate each other. This fact suggests that the factor controlling $\Delta \mathrm{H}^{*}$ must be closely related to those controlling $\Delta \mathrm{S}^{*}$. Therefore, the solubility state of the encounter complex would be important in determining $\Delta \mathrm{H}^{*}$. Thus, the relatively small enthalpy of activation, $\Delta \mathrm{H}^{*}$, can be explained in terms of the formation of more solved complex.

\section{References}

[1] Ravishankar, S. L, Baba, R. A., Rangaswamy \& gowda C D, Trans Met Chem., 32, 407 (2007).

[2] Arnold, F. H. Bio/Technology, 9, 151 (1991).

[3] Sigel, H. Inorg Chem, 19, 1411 (1980).

[4] Sigel, H.; Operschall, P. B.; Massoud, S. S.; Song, B.; Griesser, R. Dalton Trans, 46, 5521 (2006).

[5] Noda, I.; Fujieda, S.; Saito, H.; Saito, T.; Otsubo, T.; Yagita, M. International J of Immunopharmacology, 20, 15 (1998).

[6] Anna, M. D.; Gabriele, D.; Arduino, O. Clinica Chimica Acta, 274, 189 (1998).

[7] Bassil, D.; Makris, D. P.; and Kefalas, P.; Food Res. Intern., 38,395 (2005).

[8] Tiziani, S.; Sussich, F.; and Gesaro, A.; Carbohydr. Res., 338, 1083 (2003).

[9] Vold, I. M. N.; and Christensen, B. E.; Carbohydr. Res., 340, 679 (2005).

[10] Sulfab, Y.; J. Inorg. Nucl. Chem., 38, 2271 (1976).

[11] Galliford, B. D. J.; Ottaway, J. M.; Analyst, 91, 415 (1972).

[12] El-Ziri, F. R.; Sulfab, Y.; Inorg. Chim. Acta., 25, 15 (1977).

[13] Ewais, H. A.; Habib, M. A.; and Elroby, S. A.; Trans. Met. Chem., 35, 73 (2010).

[14] Ali, I. H.; and Sulfab, Y.; Int. J. Chem. Kinet.,, 43, 563 (2011).

[15] Hussein, M. A.; Abdel-Khalek, A. A.; and Sulfab, Y.; J. Chem. Soc., Dalton. Trans., 318 (1983).

[16] Ewais, H. A.; Int. J. Chem. Kinet., 40, 103 (2008).

[17] Abdel-Khalek, A. A.; Hassan. E. S.; Mohamed, A. R.; J Coord. Chem. 61, 1 (2008).

[18] Ewais, H. A.; Trans. Met. Chem., 34, 539 (2010.)

[19] Abdel-Hady, A. M.; Trans. Met. Chem., 34, 873 (2008).

[20] A Textbook of Quantitative Inorganic Analysis, $3^{\text {rd }}$ Edn., Vogel, A. I. pp. 443, Longmans, London (1961)

[21] Symons, M.C.R.; J. Chem. Soc. 2794 (1955).

[22] Determination of pH, Wily-Interscience, Bates, R.G.; NewYork (1973).

[23] Abdel-Khalek, A. A.; Ewais, H A.; Khaled, E. S. H.; and Abdel-hamied, A. Transition Met Chem., 28, 635 (2003).

[24] Abdel-Khalek, A. A.; Sayyah, S. M.; and Khaled, E. S. H.; Transition. Met. Chem., 18, 283 (1993). 
[25] Hadinec, I.; Jensovsky, L.; Linek, A.; and Synecek, V. Naturwiss., 47, 377 (1980).

[26] Ray, P.; inorg. Synth., 5, 201 (1957).

[27] Galliford, D. J. B.; Nuttall, R. H.; Ottaway, J. M.; Talanta, 19, 871 (1972).
[28] Weaver, M. J.; Yee, E. L.; Inorg. Chem., 19, 1936 (1980).

[29] Sasaki, Y.; and Kawamura, R.; Bull. Chem. Jpn., 54, 3379 (1981). 